\title{
The Obesity Epidemic
}

\author{
David Sharp
}

A Hippocratic aphorism states that "Persons who are naturally very fat are apt to die earlier than those who are slender" (Hippocrates. Aphorisms II.44, cited in Ref. 1), but it has taken the best part of 2,500 years for public health to get to grips with this essential truth. In its March/April 2004, listing of the 10 medical articles most cited in the past 2 years, an Institute for Scientific Information publication ranked an article on obesity in US adults in seventh place. ${ }^{2,3}$ By July/August, it was only one place lower and, waiting in the wings, at number 14 was the companion Centers for Disease Control and Prevention article on overweight children and adolescents. ${ }^{4}$ Put simply, $31 \%$ of US adults are obese, and $15 \%$ of children aged $6-19$ years are overweight.

Obesity is not a problem unique to the United States, of course, and similar trends are seen in Europe. ${ }^{2}$ Perhaps more surprisingly, it is not unique to city life. A recent article from the South Carolina Rural Health Research Center ${ }^{5}$ belied the notion that city dwellers are pasty in complexion, overindulgent, and idle, while country people bloom in rosy-cheeked health. The article recorded a slightly greater rate of adult obesity in rural as opposed to urban dwellers. The figures $(20.4 \%$ and $17.8 \%$, respectively) were lower than in the Centers for Disease Control and Prevention study, ${ }^{3}$ but self-reported height and weight (South Carolina) may tend to underestimate obesity based on measurement. Self-reported physical inactivity was common in both groups (62.8\% rural, $59.3 \%$ urban).

Obesity is high on the medicopolitical agenda here in the United Kingdom. Addressing a meeting on Tackling Obesity in Young People, Rosie Winterton, a Labour government minister, noted a $35 \%$ increase in obesity and overweight among children in the past 9 years, and she stated that "almost $17 \%$ of children [are] now estimated to be obese." ${ }^{6}$ A government white paper (a policy document) on public health will be published in 2004, and a significant contribution to that exercise came from Derek Wanless's inquiries. The final Wanless report appeared in February of this year. On obesity, he declared "The scale of the problem is unprecedented" (p93); over half the population of England are obese or overweight.

The British response has been a string of initiatives (the Food and Health Action Plan, the Activity Co-ordination Team, the Welfare Food Scheme, the National School Fruits Scheme, the Food in Schools Programme, and on and on). Derek Wanless is wary of targets. The previous Conservative government had aimed at reducing the prevalence of obesity to $6 \%$ of men and $8 \%$ of women by the year 2010, and that was unattainable. British people (and Americans, too, I suspect) do not like being told what to eat and so-called junk food is often cheaper than the healthier alternatives. A decade or so will have to go by before we can judge if the currently favored multiprong attack on obesity, focusing on the young, will work in Britain. It will be a struggle. In April 2004, media reports noted that children in parts of the United Kingdom were demanding the return of politically incorrect French fries (we call them chips) to school dinner menus. 


\section{REFERENCES}

1. Strauss MB, ed. Familiar Medical Quotations. Boston: Little, Brown; 1968:326.

2. Sharp DW. Americans are getting fatter-and they are not alone. Science Watch. 2004;15:5.

3. Flegal KM, Carroll MD, Ogden CL, Johnson CL. Prevalence and trends in obesity among US adults, 1999-2000. JAMA. 2002;288:1723-1727.

4. Ogden CL, Flegal KM, Carroll MD, Johnson CL. Prevalence and trends in overweight among US children and adolescents, 1999-2000. JAMA. 2002;288:1728-1732.

5. Patterson PD, Moore CG, Probat JC, Shinogle JA. Obesity and physical activity in rural America. J Rural Health. 2004;20:151-159.

6. Department of Health. Speech by Rosie Winterton MP, Minister of State, February 25, 2004, to Tackling Obesity in Young People conference. Available at: http://www.dh.gov.uk/ NewsHome/Speeches. Accessed June 10, 2004.

7. Wanless D, chair. Securing good health for the whole population. London: Her Majesty's Treasury; 2004. 